Peter Steiner

\title{
DIGITAL HUMANITIES AND RUSSIAN FORMALISM: DARWINISM AND ANTI-DARWINISM IN LITERARY HISTORY
}

The first version of this paper was presented at the Stanford Humanities Centre conference "Russian Formalism \& Digital Humanities" on April 13, 2015. It addressed Franco Moretti's provocative application of the Darwinian evolutionary model based on the divergence of biological species and their survival through the mechanism of natural selection to literary history. This approach was juxtaposed against the ideas of two leading Russian Formalists, Iurii Tynianov and Roman Jakobson, whose explanation of linguistic/literary change was programmatically anti-Darwinian making conversion (conceived, though, in a very specific way) the cornerstone of their respective historiographies. In doing so, they were reacting to the project of historical poetics advanced by the $19^{\text {th }}$ century Russian Positivist philologist, Aleksandr Veselovskii (1838-1906), whose stated goal was to trace the morphological divergences of texts across time and space. The dichotomy "conversion-diversion," my paper illustrated, is not limited to criticism alone. The same frame of reference was invoked in the late 1950's in a famous dispute between the behavioral psychologist B. F. Skinner and the father of the generativetransformational grammar, Noam Chomsky, about language acquisition and subsequently in their heated polemics about the human subject's autonomy triggered by the publication of Skinner's book Beyond Freedom and Dignity (1971). Refs 15.

Keywords: literary history, Darwinism, causality, teleology, digital humanities, Formalism, Chomsky, Jakobson, Moretti, Skinner, Veselovskii, Tynianov.

\section{Петер Штайнер \\ ЦИФРОВЫЕ ГУМАНИТАРНЫЕ НАУКИ И РУССКИЙ ФОРМАЛИЗМ: ДАРВИНИЗМ И АНТИДАРВИНИЗМ В ИСТОРИИ ЛИТЕРАТУРЫ}

Первая версия этой статьи была представлена на конференции «Русский формализм и цифровые гуманитарные науки» Стэнфордского центра гуманитарных исследований 13 апреля 2015 г. Она обращена к осуществленному Франко Моретти провокативному применению к истории литературы дарвиновской эволюционной модели, основанной на дивергенции биологических видов и их выживании через механизм естественного отбора. Этот подход сопоставляется с идеями двух ведущих представителей русского формализма - Юрия Тынянова и Романа Якобсона, чьи объяснения лингвистического/литературного изменения базировались на антидарвиновских принципах, что сделало схождение (понимаемое, правда, весьма специфическим образом) краеугольным камнем их историографий. Такой подход можно считать реакцией на проект исторической поэтики российского филолога-позитивиста XIX в. Александра Веселовского (1838-1906), который поставил задачу проследить морфологические расхождения текстов во времени и пространстве. Проиллюстрированная в данной статье дихотомия «схождения - расхождения» не сводится только к критике. Та же система отсчета была использована в конце 1950-х годов в известном споре об овладении языком между психологом-бихевиористом Б. Ф. Скиннером и «отцом» порождающей трансформационной грамматики Н. Хомским, а затем в их острой полемике по поводу автономии человеческого субъекта, инициированной публикацией книги Скиннера «За пределами свободы и достоинства» (1971). Библиогр. 15 назв.

Ключевые слова: история литературы, дарвинизм, причинность, телеология, цифровые гуманитарные науки, формализм, Хомский, Якобсон, Моретти, Скиннер, Веселовский, Тынянов.

Peter Steiner - Professor Emeritus of Slavic Studies, University of Pennsylvania, 2940 Cambridge St., Philadelphia, PA 19130, USA; psteiner@sas.upenn.edu

() Санкт-Петербургский государственный университет, 2017 
In his essay, the title of which carries a distinct Tynianovian ring to the Slavic ear, "On Literary Evolution" [1, pp. 30-47], Franco Moretti sharply separates two types of historiography: a monistic one, a.k.a. Lamarckian, that explains the development of literary forms through "a single principle of adaptation" governing both the way they are selected and the way they are modified. This he summarily dismisses as "an implausible Hegelian dream" [2, p. 263]. The Darwinian approach, which Moretti advocates, is dualistic insofar as it splits formal variations based on chance from selection ruled by necessity. For the groupies of Lamarck, evolution is a purposeful process oriented toward achieving certain goals, and only the forms congruent with this telos are boosted and passed on to the next generations. Those which don't, fall by the wayside. The Darwinists believe that the new forms are generated at random without any prior design. But to survive, they must meet the stringent selection criteria imposed by external conditions. And only the fittest, so to speak, propagate. While a pyramid with a large morphological variety at its base shrinking in time could be a graphic representation of the Lamarckian convergence stance, the ever-growing "evolutionary tree" is the emblematic image of the Darwinian divergence theory [3, pp. 67-92].

Moretti is quite aware of how unorthodox his view is in the field of cultural production, and he is ready to modify some of Darwin's original postulates to make it more applicable to his subject matter. One of those is the premise - natura non facit saltu - explaining why natural evolution is slow and incremental. This proposition, Moretti argues, does not correspond to the spasmodic nature of literary development; and thus, he replaces it with the anti-gradualist notion of "punctuated equilibrium" [2, p. 268]. I am mentioning this revision because, like Moretti, Roman Jakobson regarded the Darwinian model of morphological variations as a slow and virtually imperceptible process as an inappropriate explanatory tool for historical linguistics. Language changes, he argued, "through jumps, paroxysms, sudden mutations" [4, p. 110]. But for this very reason, and unlike Moretti, Jakobson embraced the convergence theory that conceived of biological change in precisely these terms. Furthermore, Moretti does not rule out the possibility that convergence takes place in literary history, and he pays attention to the process of amalgamation occurring in cultural evolution. The branches of the tree of knowledge are, indeed, more intertwined than the branches of the tree of life. But convergence, he argues, is merely the consequence of divergence - its, as it were, belated echo.

Turning now to the Russian critical tradition, the foremost representative of the divergence view of literary evolution was the great Positivist philologist Aleksandr Veselovskii (1838-1906), even though the intellectual model he followed was not Charles Darwin's but Herbert Spencer's. In many respects, his programme shares the passion for what Moretti termed "distant reading": gathering and analyses of massive amounts of textual data instead of looking at a single text [5]. Veselovskii eschews the study of national literatures, of literary periods, and of the great authors. His subject matter is global or universal literature (vseobshchaia) from the earliest to its latest manifestations (pre-literary folklore and mythology included). In nuce, Veselovskii's method can be characterised as inductivist and comparativist. Literary texts across the world, he announced, can be reduced to the common stock of the simplest formal elements (motifs, plot schemes, metaphors, and epithets). The task of historical poetics is to map how these elementary units branch out through literatures disparate in time and space, recombining and mutating in the process. The mechanism of such a transmission is causal - based on influences and borrowings - 
and, therefore, with sufficient data for a warranted generalisation, criticism, Veselovskii predicted, will turn into a nomothetic discipline, yielding the laws of literary evolution.

Moreover, Veselovskii's historical poetics is dualistic in the sense that the trajectory it mapped lacked any immanent direction because a totally exogenous force determined it. The history of literature is an incessant interaction between two factors: the passive artistic form and the active social content. The formal elements transcend time like linguistic patterns, and every literary work recycles them in some way. Yet, literature evolves because the inherited forms are forever imbued with new content. This content, Veselovskii maintains, is purely extra-literary in its origin - the product of transformations in social life and human spirit. But it is exclusively this external context that regulates which formal elements are actualised and how they are modified. To quote from his famous 1870 lecture, "[literary] forms relate to the changing content of the worldview through a sort of the natural selection determined by the conditions of life $[b y t]$ and the vicissitudes of history." From this perspective, then, the task of the historian is, "to investigate how the new life content, this element of freedom that rushes in with each new generation, fills the old moulds, those forms of necessity in which ineluctably the entire previous development was cast" [6, pp. 49, 52].

Veselovskii escaped the dreaded "Hegelo-Lamarckian view of literature as a realm where variations only arise if predestined for success" [2, p. 267] because the historical path comes about as a series of collisions between the supra-individual transmission of formal elements and the actual socio-cultural context. The same, however, can be said about the historiographies of Iurii Tynianov and Roman Jakobson - Veselovskii's rebellious heirs - insofar as they too decoupled the hit-or-miss morphological variations from their actual implementations. But they cast the dialectics of chance and necessity quite differently.

Let me illustrate how through a simple linguistic example. Russian, we know, until after 988 lacked the speech sound [f]. And it is quite easy to explain its eventual arrival through extra-linguistic reasons. In that year, Russia was Christianised, and a plethora of Greek texts arrived containing many instances of [f] in the names of saints, for example. So, eventually, [f] was domesticated by Russian. This answer, good as it is, begs, however, the next question. Why $[\mathrm{f}]$ and not some other sounds like $[\theta]$ or $[ð]$ which also exist in Greek but not in Russian? Here we cannot fall back on the exogenous rationale. It is the inner predisposition of language, Jakobson would argue, that determines the acceptability of a particular sound. This "single principle of adaptation" might sound metaphysical but is rather simple. The Russian phonological system contained five pairs of hard consonants related through the opposition of voiced/voiceless: $[\mathrm{b}] /[\mathrm{p}],[\mathrm{g}] /[\mathrm{k}],[\mathrm{d}] /[\mathrm{t}],[\mathrm{z}] /[\mathrm{s}]$, and $[\mathrm{zh}] /[\mathrm{sh}]$. But the lonely [v] stood out like a proverbial sore thumb. The Greek [f] easily fit into an empty slot correlating with a voiceless [v] while no such vacancy was available for either $[\theta]$ or $[ð]$. It is a telling testimony to the memory of language that until now some Russian speakers are not entirely sure about the status of [f] as attested by doublets like "shkaf/shkap" (cupboard).

This argument, as you probably recognised, derives from the Saussurian notion of la langue. The dissimilarity between voiced and voiceless consonants is phonological insofar as it can differentiate words of unlike meanings. But [f] is not merely voiced, but in contrast to the soft [f'] is also hard, and if juxtaposed to a stop [p], a fricative. In fact, this phoneme is but a combination of such distinctive features, a specific implementation 
of "the system of differences," the underlying linguistic code 1 . Yet, while applauding Saussure's separation of an actual utterance from a potential system, the Formalists parted company with him when it came to his view of la langue as a purely synchronic structure. For it was obvious to them that every language contains, at any moment, morphological, syntactic, and semantic forms with an unmistakable temporal impetus: the backwardlooking archaisms as well as the future oriented neologisms. Or, as Jakobson and Tynianov put it in their oft quoted 1928 Prague theses: "The opposition between synchrony and diachrony...loses its importance... as soon as we recognise that every system necessarily exists as an evolution... [and] ...the evolution is inescapably of a systemic nature" [8, p. 80].

How did Tynianov apply this insight to literary history? First, he bifurcated the change into two incompatible categories: its genesis on the one hand, and its evolutionary significance on the other hand. Like Moretti, he would argue that new literary forms come about in a haphazard way, the intersection of many heterogeneous impulses. But their evolutionary significance - eventual acceptance by the reading public - was the function of their convergence with the developmental tendencies of the normative literary system. From this perspective, then, it was truly irrelevant whether the morphological variations were inherited (Darwin) or acquired (Lamarck) though, it must be stressed, the Formalists clearly privileged analogy over homology. This is clear from the fact that Tynianov appointed the parody as the chief engine of literary development. Though Mother Nature does not allow cats and dogs to interbreed, literature easily marries, within a single text, such incongruous elements as "elevated rhythmical-syntactic figures" and "low' vocabulary and themes." These are Nikolai Nekrasov's early parodies of Lermontov's romantic poems which, though rather marginal in his oeuvre, paved, according to Tynianov, the road toward the prosaic character of Russian civic poetry in the 1850s [9, pp. 399-411].

But why these juvenile parodies meshed with the developmental tendency of Russian poetry? Hegel no doubt, influenced Tynianov's answer to this question though not in the sense that the Formalist critic would ascribe to literary history either a meaning or a striving toward a preordained goal. It was Hegelian dialectics which played a signal role in Tynianov's definition of a literary work as a dynamic speech construction that we perceive qua construction as long as we sense in it the struggle of the constitutive elements for domination and subordination. Nekrasov's awkward, flatfooted verse fitted the bill not because it was better than the mellifluous, graceful Romantic canon of yesteryear, but because its constructive principle - the relationship of the dominant constructive factor and the subordinate material - was radically different. And now the \$64 question: is Tynianovian historiography "unitary" or "dualistic"? As illustrated, Tynianov believes that morphological variations are generated at random (e.g., by Nekrasov's sophomoric humour). But when it comes to the selection of a particular form he, it seems, yields to "a monistic idea of literary evolution... according to which one principle, and one only... (a close kin of... 'estrangement') explains all there is to be explained" [2, pp. 266-267].

Tynianov, it must be emphasised, did not believe that the developmental ascendancy of a new poetic form is triggered by a single immanent cause, the aesthetic otherness included. And among the Formalists he was not alone. In a similar vein, Jakobson rejected a total linguistic determinism in versology, the view that the phonological system alone could explain the choice of a particular metrics by a given poetic tradition. There are other

${ }^{1}$ Cf., Saussure famous dictum: "In language, there are only differences, without positive terms," [7, p. 120]. 
extra-linguistic factors involved, he argued. True, the rhythm-creating elements, Jakobson maintained, are phonology-based. Yet Czech versification (he analysed in the early 1920s) is accentual rather than quantitative even though in Czech it is the free length, not the fixed stress that is phonological, i.e., meaning differentiating. The rationale for $19^{\text {th }}$ century Czech poetry becoming syllabotonic, Jakobson wrote, "can never be totally deduced from a given language. If a versification system is the unknown and what is given to us are only the prosodic elements of the language, we can arrive merely at an indeterminate equation, i.e., the possibility of several values for the X. An explanation for the historical choice of this or that solution from among the several possible ones involves factors that are outside the phonetics of the given language," for example, "cultural influences" [10, p. 118]. This assertion, it is easy to recognise, foreshadows the $8^{\text {th }}$ point of Jakobson's and Tynianov's theses mentioned above according to which the evolution of the literary/linguistic system is always integrated with that of other social practices into a higher whole - "the system of systems" in the Formalists' parlance [8, p. 81]. Such a cultural totality follows its own structural laws that interfere with the immanent development of language/literature, and its role in selecting the ultimate winner of the "morphological" beauty contest cannot be ignored.

At this point it might appear that what distinguishes Moretti's literary historiography from Jakobson/Tynianov's is merely their respective complexity. For the dualist Morreti, evolution is a two-stage process: the writer proposes and society disposes. The Formalists, on the other hand, conceived of the same as a three-ring circus. Between the producer and the recipient stands a peculiar filter - the normative literary system - that considerably limits the range of formal choices to be accepted or rejected. But the difference between the two, I believe, runs deeper, concerning the very relationship between literature and society. The divergence approach sees it clearly as a one-way street. "The context," to cite Morreti, "can select forms - but it cannot generate them" [2, p. 266]. The convergence theorists, on the other hand, insist that the non-literary milieu does spawn morphological variations that can turn literary if affine to the system's needs. To wit: the transition to Sentimentalism in the $18^{\text {th }}$ century Russian letters, Tynianov opined, was facilitated by the use of speech genres belonging to quotidian social intercourse (like the letter) providing literati with ready-made forms - the handy devices to be utilised in displacing the Classicist canon dominated by the ode. This mésalliance was possible because literature was just one of many discursive modalities sharing language as their medium. In fact, the rise of Sentimentalism, according to Tynianov, cannot be separated from the overall shift in the dominant communicative setting taking place in Russia at that time: the switch from the top-down formal court to the personal and playful salon cultivating the art of social conversation [11, pp. 48-86].

Divergence, convergence, literary history. But let me conclude my short presentation by pointing out that the question of whether to interpret the sequential relationship between independent and dependent variables in a monistic or a dualistic fashion is important in other fields of human science as well. The famous dispute about language acquisition between Noam Chomsky and B. F. Skinner in the late 1950s is a telling example. It was Skinner himself who drew the parallel between his radical behaviourism and Darwinian thought. The process of learning, like biological evolution, is not a goal-oriented activity, he charged, because it is solely the result of variations and selection. A random and unmotivated behaviour turns into knowledge only because it is reinforced by the 
outside world. Simply put, babbling becomes more and more speech-like because some of the sound combinations coming haphazardly from the infant's mouth receive a selective endorsement by the caregiver [12]. Chomsky's critique of Skinner's behaviourism is many faceted and I cannot do it full justice here. One of the points, which should sound familiar, is his observation that language acquisition is not a hill-climbing process of incremental gains. It moves, instead, in rapid spurts independent of the scope of the linguistic exposure to which the child is subjected during these periods (the so-called "lexical explosion"). Chomsky's explanation of how we become language proficient sounds, surprise, surprise, quite Lamarckian. The infant is able to pull together the disparate linguistic fragments it encounters early in life into a coherent system because it is born with an innate capacity to learn language, because its brain is pre-wired with the universal grammatical structure [13, pp. 26-58].

What makes these polemics even more enticing is the fact that theoretical argument spilled over into the ideological sphere. Skinner's book Beyond Freedom and Dignity [14] is a prescript for how to organise society according to the "monistic" principle of radical behaviourism and reads as if copied from Evgenii Zamiatin's We. Since all behaviour is fully determined by the environment, the belief that the human subject is autonomous cannot be sustained. But the liberal obsession with individual freedom is not merely a relic of the past, Skinner continues, but, more importantly, an inherently dangerous idea. It militates against instituting effective social control instrumental for eradicating all forms of harmful behaviour that could threaten the group's survival. The anarchically inclined Chomsky, who usually keeps his linguistics and politics apart, could not resist jumping into the fray. The thrust of his response was to demonstrate that the book's recommendations, contrary to Skinner's claim, do not use, but abuse science. Yet, despite that, Chomsky portended ominously, they might receive a warm welcome in the US, "perhaps out of fear and a sense of insecurity about the consequences of a serious concern for freedom and dignity" [15]. Oh boy, how do I wish that he were wrong!

\section{References}

1. Tynianov Iu. N. O literaturnoi evoliutsii [About evolution of literature]. Arkhaisty i novatory. Leningrad, Priboi Publ., 1929, pp. 30-47. (In Russian)

2. Moretti F. On Literary Evolution. Signs Taken for Wonders: Essays in the Sociology of Literary Forms. Transl. by Susan Fischer, David Forgacs and David Miller. London, Verso Publ., 1988, pp. 262-278.

3. Moretti F. Tree. Graphs, Maps, Trees: Abstract Models for Literary History. London, Verso Publ., 2005, pp. 67-94.

4. Roman Jakobson, "Remarques sur l'évolution phonologique du russe comparée à celle des autres langues slaves". Selected Writings 1: Phonological Studies. The Hague Mouton, Publ., 1962, pp. 7-116.

5. Moretti F. Distant Reading. London, Verso Publ., 2013. 244 p.

6. Veselovskii A. N. O metode i zadachakh istorii literatury kak nauki [Abouth method and task of history of literature as a science]. Istoricheskaia poetika. Leningrad, Khudozhestvennaia literatura Publ., 1940, pp. 41-52. (In Russian)

7. Saussure F. de Course in General Linguistics. Transl. by Wade Baskin. New York, Philosophical Library Publ., 1959. 240 p.

8. Jakobson R. and Tynianov J. Problems in the Study of Literature and Language. Transl. by Herbert Eagle. Readings in Russian Poetics: Formalist and Structuralist Views. Eds Ladislav Matejka, Krystyna Pomorska. Cambridge, MA, MIT Press Publ., 1971, pp. 79-81.

9. Tynianov Iu. Tynianov Iu. Stikhovye formy Nekrasova. Arkhaisty i novatory, Leningrad, Priboi Publ., 1929, pp. 399-411. (In Russian)

10. Jakobson R. O cheshskom stikhe - preimushchestvenno v sopostavlenii s russkim. Berlin, Moscow, OPOJAZ - MLK Publ., 1923. 120 p. (In Russian) 
11. Tynianov Iu. Oda kak oratorskii zhanr. Arkhaisty i novatory, Leningrad, Priboi Publ., 1929, pp. 4886. (In Russian)

12. Skinner B. F. Verbal Behavior. New York, Appleton-Century-Crofts Publ., 1957. 478 p.

13. Chomsky N. Review of Skinner's. Verbal Behavior. Language, 1959, vol. 35, no. 1, pp. 26-58.

14. Skinner B. F. Beyond Freedom and Dignity. New York, Knopf Publ., 1971. 225 p.

15. Chomsky N. The Case Against B. F. Skinner. New York Review of Books. December 30, 1971. Avialable at: http://www.nybooks.com/articles/1971/12/30/the-case-against-bf-skinner/ (accessed 24.01.2017).

For citation: Steiner Peter. Digital Humanities and Russian Formalism: Darwinism and anti-Darwinism in Literary History. Vestnik SPbSU. Philosophy and Conflict Studies, 2017, vol. 33, issue 2, pp. 217-223.

DOI: $10.21638 / 11701 /$ spbu17.2017.209

Received: 17.12 .2016

Accepted: 15.12.2016 